\title{
Increased salinity improves the thermotolerance of mesophilic nitrification
}

\author{
Emilie N. P. Courtens - Nico Boon • Peter De Schryver • \\ Siegfried E. Vlaeminck
}

Received: 27 November 2013 / Revised: 8 January 2014 / Accepted: 9 January 2014 / Published online: 14 February 2014

(C) Springer-Verlag Berlin Heidelberg 2014

\begin{abstract}
Nitrification is a well-studied and established process to treat ammonia in wastewater. Although thermophilic nitrification could avoid cooling costs for the treatment of warm wastewaters, applications above $40{ }^{\circ} \mathrm{C}$ remain a significant challenge. This study tested the effect of salinity on the thermotolerance of mesophilic nitrifying sludge $\left(34^{\circ} \mathrm{C}\right)$. In batch tests, $5 \mathrm{~g} \mathrm{NaCl} \mathrm{L}^{-1}$ increased the activity of aerobic ammonia-oxidizing bacteria (AerAOB) by $20-21 \%$ at 40 and $45{ }^{\circ} \mathrm{C}$. For nitrite-oxidizing bacteria (NOB), the activity remained unaltered at $40{ }^{\circ} \mathrm{C}$, yet decreased by $83 \%$ at $45{ }^{\circ} \mathrm{C}$. In a subsequent long-term continuous reactor test, temperature was increased from 34 to $40,42.5,45,47.5$ and $50{ }^{\circ} \mathrm{C}$. The AerAOB activity showed 65 and $37 \%$ higher immediate resilience in the salt reactor $\left(7.5 \mathrm{~g} \mathrm{NaCl} \mathrm{L}^{-1}\right)$ for the first two temperature transitions and lost activity from $45^{\circ} \mathrm{C}$ onwards. NOB activity, in contrast to the batch tests, was 37 and $21 \%$ more resilient in the salt reactor for the first two transitions, while no difference was observed for the third temperature transition. The control reactor lost NOB activity at $47.5^{\circ} \mathrm{C}$, while the salt reactor only lost activity at $50{ }^{\circ} \mathrm{C}$. Overall, this study demonstrates salt amendment as a tool for a more efficient temperature transition for mesophilic sludge $\left(34^{\circ} \mathrm{C}\right)$ and eventually higher nitrification temperatures.
\end{abstract}

Electronic supplementary material The online version of this article (doi:10.1007/s00253-014-5540-y) contains supplementary material, which is available to authorized users.

E. N. P. Courtens $\cdot$ N. Boon $(\triangle) \cdot$ S. E. Vlaeminck Laboratory of Microbial Ecology and Technology (LabMET), Ghent University, Coupure Links 653, 9000 Gent, Belgium

e-mail: Nico.Boon@UGent.be

P. De Schryver

Laboratory of Aquaculture and Artemia Reference Center, Ghent

University, Rozier 44, 9000 Gent, Belgium
Keywords Adaptation $\cdot$ Nitrospira $\cdot$ Nutrient removal $\cdot$ Salt stress

\section{Introduction}

Nitrogen compounds are major wastewater components that can cause severe problems to global ecology and society when released into the environment. Physico-chemical processes such as stripping and struvite precipitation can be used to recover nitrogen, but biological nitrogen removal is the most cost-efficient option for regular domestic and industrial wastewaters $\left(<5 \mathrm{~g} \mathrm{~N} \mathrm{~L}^{-1}\right)$ (Mulder 2003). Nitrification/ denitrification is the most important biological nitrogen removal application, whereas partial nitritation/anammox is gaining importance during the last years (Vlaeminck et al. 2012). Nitrification is the oxidation of ammonia to nitrite by aerobic ammonium-oxidizing bacteria and/or archaea (AerAOB/AOA), i.e. nitritation, followed by nitratation, the oxidation of nitrite to nitrate by aerobic nitrite-oxidizing bacteria (NOB). Anammox is performed by anoxic ammoniumoxidizing bacteria (AnAOB) combining the ammonium with nitrite to mainly nitrogen gas and some nitrate.

Temperature is a crucial environmental parameter for nitrogen removal, particularly for the aerobic processes. Reactors with nitrification or nitritation are typically run in the range of $5-35{ }^{\circ} \mathrm{C}$ (Guo et al. 2010; Ilies and Mavinic 2001), while the optimum reaction rates for denitrification occur at $35-50{ }^{\circ} \mathrm{C}$ (Barnes and Bliss 1983). The recent discovery of the AOA Nitrosocaldus yellowstonii, growing up to $74{ }^{\circ} \mathrm{C}$, however shows the ecologic and evolutionary importance of nitrification at high temperatures (de la Torre et al. 2008). Although some nitrogen-converting organisms were detected and/or enriched in batch cultures from a natural thermophilic environment such as deep-sea hydrothermal vents and hot springs (Golovacheva 1976; Hatzenpichler 
et al. 2008; Lebedeva et al. 2011), no continuous thermophilic nitrogen-converting communities were described that have a potential to be used in practice. Nitrification above $40^{\circ} \mathrm{C}$ can be observed in industrial wastewater applications, but is not documented to our knowledge. Until now, thermophilic nitrogen removal has mainly been investigated as a part of studies focusing on thermophilic activated sludge (Abeynayaka and Visvanathan 2011; Kurian et al. 2005). Oxidation of organic material was the main goal in those studies, and the exact fate of nitrogen in these systems remained unclear. The main nitrogen removal mechanisms in these thermophilic systems are assumed to be ammonia stripping and nitrogen assimilation into biomass. Abeynayaka and Visvanathan (2011) attributed $60 \%$ of the ammonium removal to ammonia stripping, $20 \%$ to nitrogen assimilation by the biomass and only $20 \%$ to nitrification, both at 47 and $60{ }^{\circ} \mathrm{C}$. However, Kurian et al. (2005) found at $45^{\circ} \mathrm{C}$ that ammonia stripping accounted for $75-83 \%$ of the ammonium removal and assimilation for 16$25 \%$, without nitrification being involved. $\mathrm{As} \mathrm{NH}_{3}$ stripping shifts the nitrogen problem to the gas phase, and the $\mathrm{C} / \mathrm{N}$ ratio in high-strength nitrogenous wastewaters is too low to obtain sufficient nitrogen removal based on assimilation, development of thermophilic nitrification is necessary. Besides the thermophilic activated sludge studies, Lopez-Vazquez et al. (2013) recently detected nitrifying activity in mesophilic sludge from an industrial wastewater treatment plant after temperature shocks of as high as $50^{\circ} \mathrm{C}$. An immediate activity loss was observed at $55{ }^{\circ} \mathrm{C}$. These batch activity tests were performed on a short term (hours), yet the effect on a longer term of thermophilic conditions on mesophilic sludge has not been detailed yet.

Thermophilic aerobic processes are known to be more stable, to achieve higher rates (smaller bioreactors can be used), to produce less biological sludge and to achieve better hygienization (Lapara and Alleman 1999). Additionally, elimination of cooling requirements would result in lower investment costs (capex). Thermophilic nitrification could thus be of interest for the removal of nitrogen from high-temperature industrial wastewater (e.g. fertilizer and paper industry) (Shore et al. 2012), municipal wastewater with high seasonal temperatures (Lubkowitz-Bailey and Steidel 1999), livestock manure, supernatant from thermophilic anaerobic digesters or from the so-called autothermal aerobic digestion processes (Liu et al. 2010).

The adaptive capacities of microbial communities to changing temperatures have been described, for instance for activated sludge systems (Suvilampi and Rintala 2003). Acclimatization periods are mostly needed, but some factors can improve resistance to higher temperatures. In food preservation for example, high osmolarity induced an increased thermotolerance in Salmonella (Fletcher and Csonka 1998). As a response to osmotic stress, microorganisms accumulate osmoprotectants. The role of those compatible solutes can also protect the cell or cell components from other environmental constraints such as freezing, desiccation, oxygen radicals and high temperature (Welsh 2000). These findings suggest that, although a salt shock is known to inhibit both AerAOB and NOB (Moussa et al. 2006), the associated induction of compatible solutes may also help nitrifiers to maintain their activity at higher temperatures.

This study investigated whether increased salinity can enhance the thermotolerance of a mesophilic nitrifying community. Firstly, in batch activity tests, both the effect of different salt concentrations at $40{ }^{\circ} \mathrm{C}$ and the effect of $5 \mathrm{~g} \mathrm{NaCl} \mathrm{L}^{-1}$ at different temperatures were explored, measuring not only immediate activity but also activity after $48 \mathrm{~h}$. Subsequently, a continuous experiment with fed-batch reactors was used to evaluate salt amendment $\left(7.5 \mathrm{~g} \mathrm{NaCl} \mathrm{L}^{-1}\right)$ between 34 and $50^{\circ} \mathrm{C}$. Besides physico-chemical measurements, the nitrifying community was closely monitored by microbial and molecular analyses.

\section{Materials and methods}

Activity batch tests

Aerobic batch experiments were performed as described by Windey et al. (2005). Initially, a screening test at 34 and $40{ }^{\circ} \mathrm{C}$ with addition of $5 \mathrm{~g} \mathrm{NaCl} \mathrm{L}^{-1}$ was performed on two different inocula containing AerAOB and NOB. Conventional activated sludge (CAS) and sludge from a biological nutrient removal (BNR) reactor were used. Besides the nitrifying AerAOB and NOB, the CAS and the BNR sludge contained additional aerobic heterotrophs and additional anammox bacteria (AnAOB), respectively. The CAS was freshly collected from a sewage treatment plant (Destelbergen, Belgium), operating at a yearly average temperature of $15{ }^{\circ} \mathrm{C}$, while the BNR sludge was harvested from a mature lab-scale rotating biological contactor operating at $34{ }^{\circ} \mathrm{C}$ for 10 years and fed with synthetic influent $\left(1 \mathrm{~g} \mathrm{~N} \mathrm{~L}^{-1}\left(\mathrm{NH}_{4}\right)_{2} \mathrm{SO}_{4}, 7.5 \mathrm{~g} \mathrm{NaHCO}_{3} \mathrm{~g}^{-1} \mathrm{~N}\right.$ and $308 \mathrm{mg} \mathrm{KH}_{2} \mathrm{PO}_{4} \mathrm{~L}^{-1}$ (Pynaert et al. 2003). As only the BNR sludge showed significant effects, tests were proceeded with this biomass. Firstly, at $40^{\circ} \mathrm{C}$, the effect of different salt concentrations $\left(0,2,5\right.$ and $\left.8 \mathrm{~g} \mathrm{NaCl} \mathrm{L}^{-1}\right)$ was tested. Secondly, a dosage of $5 \mathrm{~g} \mathrm{NaCl} \mathrm{L}^{-1}$ above the salinity of the cultivation reactor $\left(5.4 \mathrm{~g} \mathrm{~L}^{-1} \mathrm{NaCl}\right.$ equivalents) was tested at three different temperatures $\left(31,40\right.$ and $\left.45^{\circ} \mathrm{C}\right)$ and both the direct activity and the activity after $48 \mathrm{~h}$ were determined. The aerobic tests were all performed in open Erlenmeyer flasks with ammonium as the substrate $\left(\mathrm{NH}_{4} \mathrm{Cl}, 50 \mathrm{mg} \mathrm{N} \mathrm{L}^{-1}\right)$ and a pH 7 buffering solution with final concentrations of $1 \mathrm{~g}$ $\mathrm{NaHCO}_{3} \mathrm{~L}^{-1}, 4.2 \mathrm{~g} \mathrm{KH}_{2} \mathrm{PO}_{4} \mathrm{~L}^{-1}$ and $5.8 \mathrm{~g} \mathrm{~K}_{2} \mathrm{HPO}_{4} \mathrm{~L}^{-1}$. Ammonium, nitrite and nitrate concentrations were monitored $8 \mathrm{~h}$ after substrate addition. The direct specific activity was calculated based on the partial nitritation/anammox 
stoichiometry (Vlaeminck et al. 2012) after the first substrate addition (substrate added after acclimatization of the sludge to the tested temperature), whereas the activity after $48 \mathrm{~h}$ was calculated after a second substrate addition. In short, the nitrogen loss was assigned to AnAOB activity and AerAOB activity was calculated based on the ammonium removal, taking into account the contribution of the AnAOB activity. Similarly, the NOB activity was calculated based on the nitrate production, taking into account the nitrate production by the anammox $\left(0.26\right.$ mole $\mathrm{NO}_{3}{ }^{-}$produced $/$mole $\mathrm{NH}_{4}{ }^{+}$removed $)$. All tests were performed in triplicate on a shaker $(100 \mathrm{rpm})$, including an abiotic control for stripping and a control without $\mathrm{NaCl}$ addition for each temperature.

\section{Reactor set-up and operation}

The two parallel fixed-bed (AnoxKaldnes K1 carriers) reactors (salt and control) had an effective liquid volume of $2 \mathrm{~L}$, had an inner diameter of $12 \mathrm{~cm}$ and were operated in a sequential batch feeding/withdrawal mode. The 1-h cycle consisted of a 50-min aerobic reaction period including a 6min feeding period at the beginning of the cycle, followed by a 5 -min settling period and a 5-min decanting period. The reactors were inoculated with BNR sludge originating from a rotating biological contactor as described by Pynaert et al. (2003) at an initial biomass concentration of $3.3 \pm 0.1 \mathrm{~g}$ volatile suspended solids (VSS) $\mathrm{L}^{-1}$. In order to estimate the amount of $\mathrm{NH}_{3}$ stripping during operation, hydraulic tests (without biomass) were performed in the reactors before start-up at $\mathrm{pH} 8,50{ }^{\circ} \mathrm{C}$ and varying $\mathrm{NH}_{4}^{+}$concentrations. Reactors were fed with a synthetic medium consisting of $\left(\mathrm{NH}_{4}\right)_{2} \mathrm{SO}_{4}\left(50 \mathrm{mg} \mathrm{N} \mathrm{L}^{-1}\right), 7 \mathrm{~g} \mathrm{NaHCO}_{3} \mathrm{~g} \mathrm{~N}^{-1}(1.17 \mathrm{~mol}$ $\left.\mathrm{NaHCO}_{3} \mathrm{~mol}^{-1} \mathrm{~N}\right)$ and $\mathrm{KH}_{2} \mathrm{PO}_{4}\left(10 \mathrm{mg} \mathrm{P} \mathrm{L}{ }^{-1}\right)$ dissolved in tap water resulting in a salinity of $2 \mathrm{~g} \mathrm{~L}^{-1} \mathrm{NaCl}$ equivalents. The influent of the salt reactor was supplemented with $7.5 \mathrm{~g}$ $\mathrm{NaCl} \mathrm{L}^{-1}$. As less bicarbonate was dosed in the reactor influent compared with the batch tests, a higher $\mathrm{NaCl}$ concentration was dosed here in order to reach the same final conductivity as in the batch tests. The reactor vessels were jacketed, and the temperature was controlled with a circulating thermostatic water bath. After a start-up period of 14 days at $34{ }^{\circ} \mathrm{C}$, the temperature of both was gradually increased to $40,42.5$, $45,47.5$ and $50{ }^{\circ} \mathrm{C}$ on days $14,88,130,180$ and 193 , respectively. Temperature was increased after 2 weeks of stabilization, except for the $40{ }^{\circ} \mathrm{C}$ period, where each reactor suffered from a $\mathrm{pH}$ control failure and a longer stabilization period was applied. At 40 and $42.5^{\circ} \mathrm{C}$, a 2 -week period where no $\mathrm{NaCl}$ was added to the feed of the salt reactor was also included.

In principle, the influent nitrogen concentrations were kept stable. However, from the moment that AerAOB activity decreased, the influent $\mathrm{NH}_{4}^{+}$concentration was lowered from 50 to $20 \mathrm{mg} \mathrm{N} \mathrm{L}^{-1}$ to avoid higher free ammonia (FA) concentrations. FA concentrations were calculated based on $\mathrm{pH}, \mathrm{T}$ and ionic strength, as described by Bell et al. (2008) and reached $0.30 \pm 0.23$ and $0.19 \pm 0.35 \mathrm{mg} \mathrm{N} \mathrm{L}^{-1}$ in the control and salt reactor, respectively. From the moment AerAOB activity decreased, nitrite was additionally dosed in the influent as $\mathrm{NaNO}_{2}\left(50 \mathrm{mg} \mathrm{N} \mathrm{L}{ }^{-1}\right)$ to prevent $\mathrm{NOB}$ substrate limitation and thus underestimation of the NOB activity, as done from day 23 in the control reactor and from day 58 in the salt reactor (Fig. 4(b)).

The reactor $\mathrm{pH}$ was controlled between $\mathrm{pH} 6.8$ and 7.0 by a dosage of $0.1 \mathrm{M} \mathrm{NaOH} / \mathrm{HCl}$ in order to minimize FA stripping and avoid high FA concentrations at higher temperatures. $\mathrm{pH}$ value averages of $6.88 \pm 0.18$ and $6.91 \pm 0.16$ for the control and salt reactor were reached, respectively. High pressure air pumps provided aeration through a diffuser stone at an average superficial air flow rate of $1.33 \mathrm{~m}^{3} \mathrm{~m}^{-2} \mathrm{~h}^{-1}$, resulting in dissolved oxygen (DO) concentrations of $3.94 \pm 1.23$ and 4.06 $\pm 1.14 \mathrm{mg} \mathrm{O}_{2} \mathrm{~L}^{-1}$ for the control and salt reactor, respectively. Flow rates were not significantly different $(7.5 \pm 1.0$ and $7.8 \pm$ $1.2 \mathrm{~L} \mathrm{day}^{-1}$, for the control and salt reactors, respectively), resulting in similar hydraulic retention times (HRT) of $6.51 \pm$ 0.80 and $6.12 \pm 0.60 \mathrm{~h}$, respectively.

Consistent with the batch tests, the AerAOB and NOB volumetric activities were calculated based on the partial nitritation/anammox stoichiometry (Eqs. 1 and 2) and average activities were calculated at stable periods of a minimum 5 days.

$$
\begin{aligned}
\operatorname{AerAOB}\left(\mathrm{mg} \mathrm{NL}^{-1} \mathrm{day}^{-1}\right)= & P_{\mathrm{NO} 2}+\mathrm{NOB}+1.32 / 2.32 \\
& \times\left(R_{\mathrm{N}}+\left(0.11 / 0.89 \times R_{\mathrm{N}}\right)\right)
\end{aligned}
$$

$\operatorname{NOB}\left(\mathrm{mg} \mathrm{N} \mathrm{L}^{-1}\right.$ day $\left.^{-1}\right)=P_{\mathrm{NO}_{3}}-\left(0.11 / 0.89 \times R_{\mathrm{N}}\right)$

Herein, $R_{\mathrm{N}}$ is the nitrogen removal rate by AnAOB $(\mathrm{mg} \mathrm{N}$ $\left.\mathrm{L}^{-1} \mathrm{~d}^{-1}\right), P_{\mathrm{NO} 2}$ is the part of the AerAOB nitrite production rate that was not consumed by NOB or AnAOB $\left(\mathrm{mg} \mathrm{N} \mathrm{L}^{-1} \mathrm{~d}^{-1}\right)$ and $P_{\mathrm{NO} 3}$ is the nitrate production rate produced by $\mathrm{NOB}$ and AnAOB (mg N L $\left.{ }^{-1} \mathrm{~d}^{-1}\right)$.

\section{Chemical analyses}

Ammonium (Nessler method) and VSS were measured according to standard methods (Greenberg et al. 1992). Nitrite and nitrate were determined on a 761 Compact Ion Chromatograph (Metrohm, Switzerland) equipped with a conductivity detector. DO and $\mathrm{pH}$ were measured with, respectively, a HQ30d DO meter (Hach Lange, Germany) and an electrode installed on a $\mathrm{R} 305 \mathrm{pH}$ controller (Consort, Belgium). Fatty acid methyl esters (FAMEs) from the biomass were prepared by transesterification for identification by a gas chromatograph (Coutteau and Sorgeloos 1995). 
Molecular analyses of the microbial communities

Fluorescence in situ hybridization (FISH) was used to determine the NOB genus, i.e. distinguish between Nitrobacter and Nitrospira, as a supporting analysis for the NOB target choice in the following quantitative polymerase chain reaction (qPCR) analysis. Inoculum and endpoint samples were examined by FISH as described by Vlaeminck et al. (2010).

qPCR was used to quantify the abundance of AOA, AerAOB, NOB and AnAOB over time. Biomass samples were taken from the inoculum and before each change in temperature or salt concentration. DNA extraction and qPCR were performed according to De Clippeleir et al. (2012) targeting the functional amoA gene for AerAOB and AOA and the 16S rRNA genes of the AnAOB (Kuenenia and Brocadia) and Nitrospira sp.

Denaturing gradient gel electrophoresis (DGGE) was used to evaluate the AerAOB community evolution. An inoculum sample was compared with the samples of both reactors at the end of each temperature period. Nested PCR and DGGE were performed based on the primers CTO189ABf, CTO189Cf and CTO653r for $\beta$-proteobacterial AerAOB (Pynaert et al. 2003). The obtained DGGE patterns were subsequently processed with BioNumerics software (Applied Maths, Belgium).

\section{Results}

Batch activity tests

Batch activity tests were used to determine the effect of salt addition on the specific AerAOB and NOB microbial activities. Screening experiments with CAS at 34 and $40^{\circ} \mathrm{C}$ did not show any beneficial effect of salt addition (Fig. 1). At $34^{\circ} \mathrm{C}$, addition of $5 \mathrm{~g} \mathrm{NaCl} \mathrm{L}^{-1}$ inhibited AerAOB and NOB by 37 and $91 \%$ respectively. Moreover, at $40{ }^{\circ} \mathrm{C}$, nearly complete inhibition of NOB was observed. Therefore, the BNR sludge was used further on in this study, initially testing different $\mathrm{NaCl}$ concentrations $\left(0,2,5\right.$ and $\left.8 \mathrm{~g} \mathrm{~L}^{-1}\right)$ at $40{ }^{\circ} \mathrm{C}$ (Fig. 2). Although no effect could be observed on the NOB activity, the AerAOB activity increased with increasing $\mathrm{NaCl}$ concentration until a maximum at $5 \mathrm{~g} \mathrm{NaCl} \mathrm{L}^{-1}$. At $8 \mathrm{~g} \mathrm{NaCl} \mathrm{L}^{-1}$, activity declined, showing no significant difference to the control treatment (Fig. 2). Consequently, a concentration of $5 \mathrm{~g} \mathrm{NaCl} \mathrm{L}^{-1}$ was used to test its effect at three different temperatures (Fig. 3). In both the control and salt treatment of $5 \mathrm{~g} \mathrm{NaCl} \mathrm{L}^{-1}$, specific activities decreased with increasing temperature. The lowest temperature tested was $34^{\circ} \mathrm{C}$, the temperature corresponding to the temperature of the BNR reactor. At $34{ }^{\circ} \mathrm{C}$, salt addition induced no significant immediate changes for AerAOB and NOB activity. Also after $48 \mathrm{~h}$, no salt effect could be detected, Whereas NOB activity was not affected by salt addition at $40^{\circ} \mathrm{C}$, the immediate AerAOB

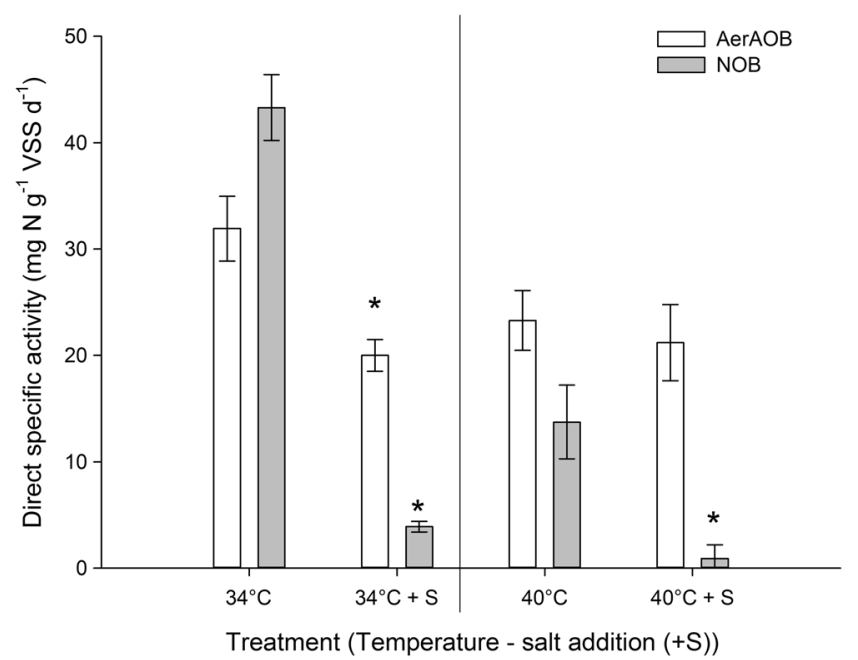

Fig. 1 Effect of salt addition $\left(5 \mathrm{~g} \mathrm{NaCl} \mathrm{L}^{-1}\right)$ on the direct specific AerAOB and NOB activities of the CAS. All experiments were performed in triplicate, and statistically significant differences $(p<0.05)$ between the control and the salt addition are indicated with an asterisk

activity increased by $21 \%$ compared to the control treatment at $40{ }^{\circ} \mathrm{C}$. However, after $48 \mathrm{~h}$, no significant activity effect of salt addition could be observed anymore. The same phenomenon was observed at $45^{\circ} \mathrm{C}$, where the salt addition increased the immediate AerAOB activity by $20 \%$. While for the AerAOB salt addition had a positive effect on the activity, for the NOB, salt addition decreased the direct activity at $45{ }^{\circ} \mathrm{C}$ by $83 \%$. After $48 \mathrm{~h}$ at $45{ }^{\circ} \mathrm{C}$, no AerAOB activity could be detected anymore. Consequently, as no nitrite was added in this test and not produced by the AerAOB, the NOB activity could not be determined. Besides AerAOB and NOB, the BNR sludge also contained AnAOB. The presence of anoxic zones resulted in a nitrogen loss of $37 \pm 11 \%$. Both at

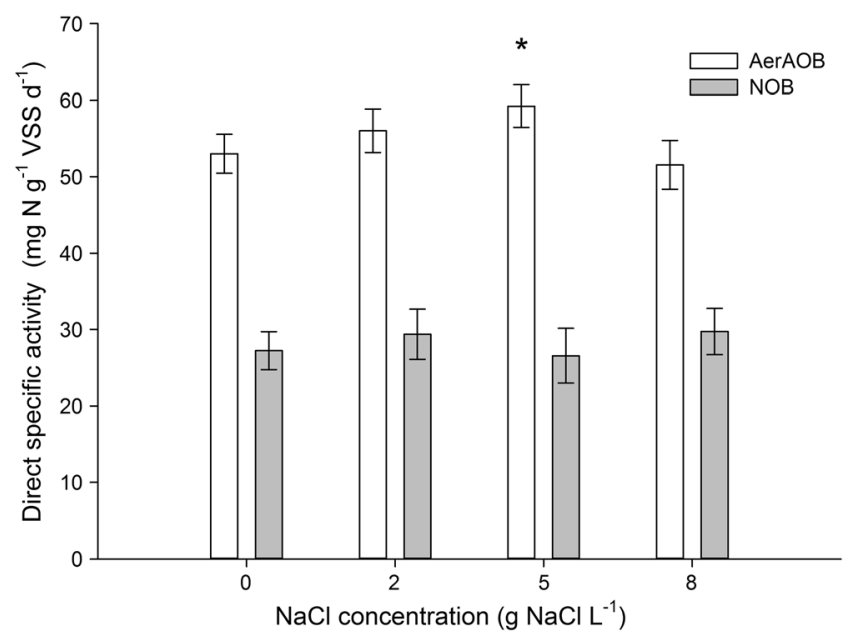

Fig. 2 Effect of different salt concentrations on the direct specific AerAOB and NOB activities of the BNR sludge. All experiments were performed in triplicate, and statistically significant differences $(p<0.05)$ between the control and the salt addition are indicated with an asterisk 

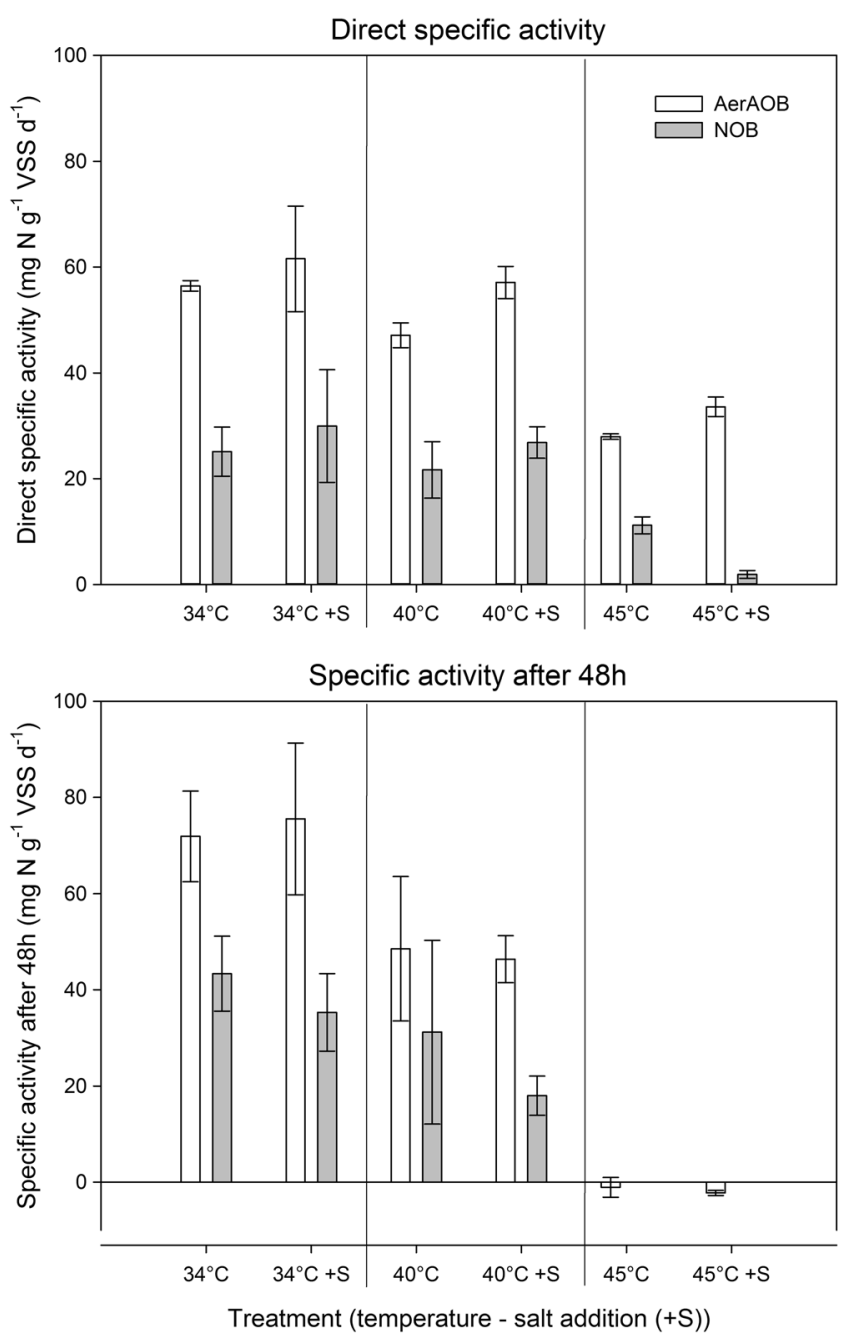

Fig. 3 Effect of salt addition $\left(5 \mathrm{~g} \mathrm{NaCl} \mathrm{L}^{-1}\right)$ on the specific AerAOB and NOB activities of the BNR sludge at different temperatures $(34,40$ and $45^{\circ} \mathrm{C}$ ). Both the direct specific activity (top) and the specific activity after $48 \mathrm{~h}$ (bottom) were determined. All experiments were performed in triplicate, and statistically significant differences $(p<0.05)$ between the control and the salt addition treatment are indicated with an asterisk

34 and $40{ }^{\circ} \mathrm{C}$, the addition of salt decreased the AnAOB activity (Fig. S1 in the Electronic Supplementary Material, ESM). After $48 \mathrm{~h}$, AnAOB activity could only be detected at $34{ }^{\circ} \mathrm{C}$. To confirm the observed salt-induced thermotolerance on AerAOB and exclude a possible starvation effect, a longterm reactor experiment was conducted.

\section{Parallel reactor tests}

A control reactor and a salt reactor were set up in parallel to investigate the effect of salt addition on the thermotolerance of AerAOB and NOB. The imposed temperature profile, salt dosage and influent nitrogen concentrations are shown in Fig. 4(a, b). Figure 4(c, d) shows the measured effluent nitrogen concentration and the resulting calculated AerAOB and NOB volumetric activities. During the elevated temperature periods $\left(>40{ }^{\circ} \mathrm{C}\right.$ ), a minor nitrogen loss of $1 \pm 4$ and $9 \pm 6 \%$ was observed in the control and salt reactor, respectively, indicating that nitrification was the main process involved. Moreover, hydraulic stripping tests in the reactors reveal that $6 \mathrm{mg} \mathrm{N} \mathrm{L}^{-1} \mathrm{day}^{-1}$ is stripped at $\mathrm{pH} 8,55^{\circ} \mathrm{C}$ and $20 \mathrm{mg} \mathrm{NH}_{4}^{+} \mathrm{L}^{-1}$ (Fig. S2 in the ESM). Since the reactors were controlled at $\mathrm{pH} 7$ and the temperature was mostly much lower than $50{ }^{\circ} \mathrm{C}$, stripping accounted for $<<4 \%$ of the nitrogen loading. Furthermore, assimilation of nitrogen into biomass is minimal for autotrophic nitrifiers (Barnes and Bliss 1983), accounting for about $2.3 \%$ of the converted nitrogen.

After a start-up period of 14 days, stable nitrification rates of $229 \pm 40$ and $134 \pm 10 \mathrm{mg} \mathrm{N} \mathrm{L}^{-1}$ day $^{-1}$ were reached for the control and the salt reactor, respectively (Fig. 4(d)). Increasing the temperature from 34 to $40{ }^{\circ} \mathrm{C}$ (day 15, Fig. 4(a)) initially decreased the specific AerAOB and NOB activities in the control reactor by 90 and $88 \%$, respectively, resulting in the build-up of ammonium of up to $46 \mathrm{mg} \mathrm{N} \mathrm{L}^{-1}$ (Fig. 4(c)). The salt reactor was more resistant to this temperature shock as the immediate decrease in activities for AerAOB and NOB was only 25 and $51 \%$, respectively. Together, these data refer to a $65 \%(=90-25 \%)$ and $37 \%$ $(=88-51 \%)$ temperature resistance improvement for nitritation and nitratation, respectively. The nitrification in the salt reactor restored nearly completely after 20 days. However, in the control reactor, only the NOB could restore entirely, while the AerAOB only regained $54 \%$ of their activity present before the temperature increase. While at $34{ }^{\circ} \mathrm{C}$, no significant differences in FA could be observed between both reactors. At $40{ }^{\circ} \mathrm{C}$, the control reactor reached significantly higher $\mathrm{FA}$ values. However, the salt reactor was performing better and a possible effect of substrate availability can thus be excluded. During the $40{ }^{\circ} \mathrm{C}$ period, both reactors suffered from a $\mathrm{pH}$ control failure resulting in a temporary drop in activity at days 43 and 68 for the control and salt reactor, respectively.

Raising the temperature from 40 to $42.5{ }^{\circ} \mathrm{C}$ on day 88 (Fig. 4(a)) showed a similar salt protection trend. No significant changes in activity were observed in the salt reactor, while in the control reactor, AerAOB and NOB activity decreased by 36 and $21 \%$, respectively (Fig. 4(d)).

After the temperature further increased to $45{ }^{\circ} \mathrm{C}$, the AerAOB activity disappeared completely in both reactors, rendering $42.5{ }^{\circ} \mathrm{C}$ as the maximum cultivation temperature for AerAOB in this study with ammonium oxidation rates of $113 \pm 13$ and $184 \pm 9 \mathrm{mg} \mathrm{N} \mathrm{L}^{-1}$ day $^{-1}$ in the control and salt reactor, respectively (Fig. 4(d)). For $\mathrm{NOB}$, transition from 42.5 to $45{ }^{\circ} \mathrm{C}$ resulted in an activity drop. However, this was transient and entirely due to nitrite limitation derived from AerAOB's activity loss. Indeed, increased dosage of nitrite in the influent 
Fig. 4 Operation and performance characteristics of control (left) and salt reactor (right). A Temperature and influent $\mathrm{NaCl}$ dosage. $B$ Influent nitrogen concentrations $C$ Effluent nitrogen concentrations. $D$ Volumetric AerAOB and NOB activity

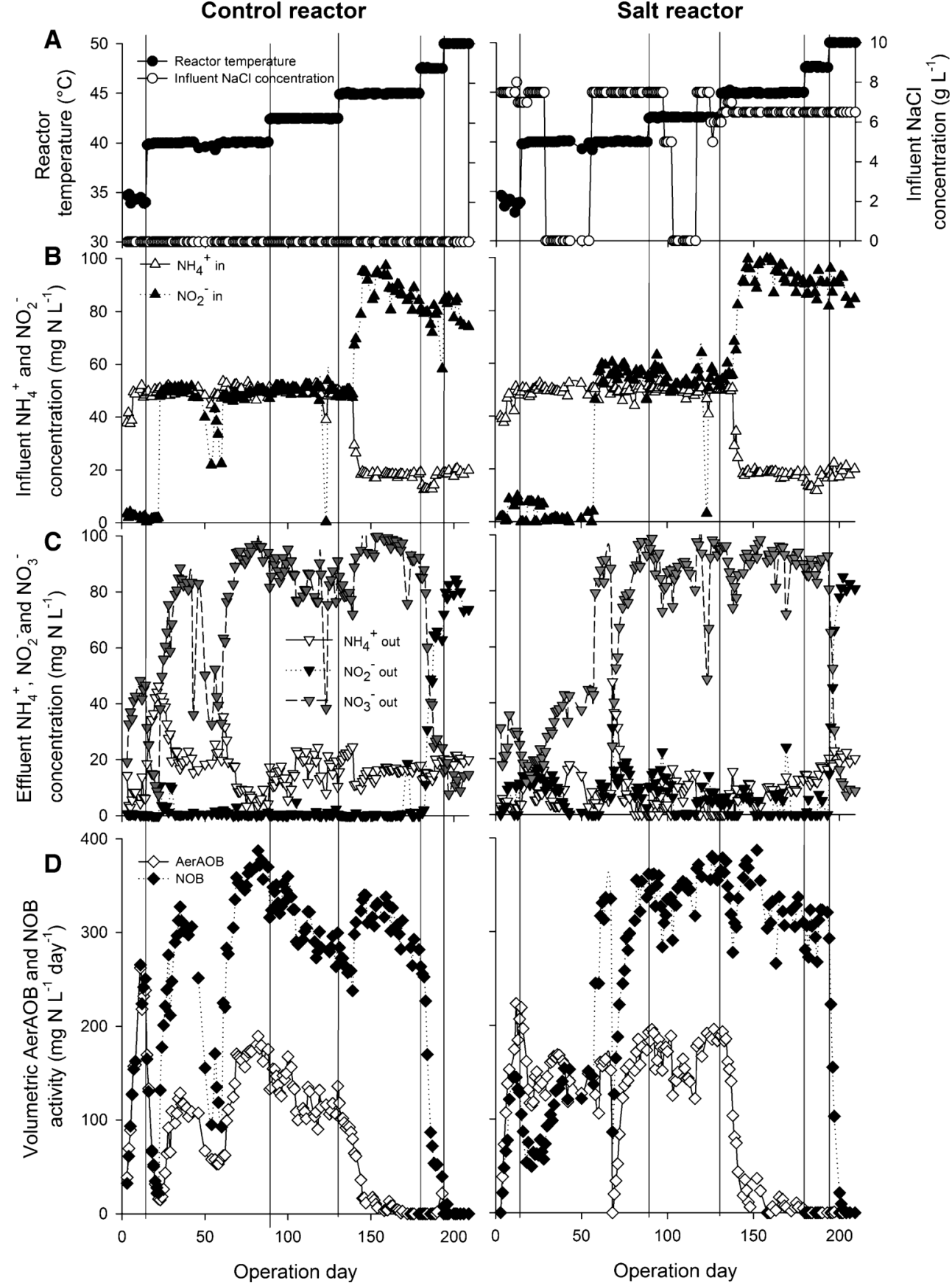

(Fig. 4(b)) restored the NOB activity at the level before the temperature increases.

Raising the temperature from 45 to $47.5^{\circ} \mathrm{C}$ led to a constant NOB activity for the salt reactor $\left(302 \pm 21 \mathrm{mg} \mathrm{N} \mathrm{L}^{-1}\right.$ day $\left.{ }^{-1}\right)$, yet the control reactor practically lost all nitratation activity, achieving a steady state of about 5 days at $49 \pm$ $7 \mathrm{mg} \mathrm{N} \mathrm{L}{ }^{-1}$ day $^{-1}$. The salt reactor finally lost its nitratation activity after the final increase to $50^{\circ} \mathrm{C}$. Overall, NOB activity could be maintained until $47.5^{\circ} \mathrm{C}$ with a sixfold higher activity in the salt reactor than in the control reactor (Fig. 4(d)).
In order to investigate whether the salt was essential in the functioning of the salt reactor, a period without salt addition was included, both at 40 and $42.5^{\circ} \mathrm{C}$ (Fig. 4(a)). At $40{ }^{\circ} \mathrm{C}$, removing the salt had no effect on the AerAOB activity but did increase the NOB activity (Fig. 4(d)). At $42.5^{\circ} \mathrm{C}$, removal of the salt did not affect the NOB, but affected the AerAOB activity with a decrease of $19 \%$ (Fig. 4(d)). Restarting salt addition, however, increased AerAOB activity to the original level. This decrease is however small compared with the AerAOB activity decrease of $90 \%$ after the first temperature 
transition, indicating that salt addition is more essential during the temperature transition than for a good performance after the temperature raise.

\section{FAME profiles}

The FAME profiles allow studying of biomass fatty acid composition, reflecting among others the membrane fluidity. No major differences could be observed in the FAME results between both reactors at day 148 (Table S1 in the ESM). Over time, some clear changes occurred in the reactors compared to the inoculum, indicating a clear temperature effect. The saturated fatty acid 16:0 almost doubled in abundance, while some unsaturated fatty acids such as $14: 1(n-5)$ and 16:1(n-7) decreased, suggesting hydrogenation of unsaturated fatty acids (Table S1 in the ESM). This phenomenon is clearly illustrated in the evolution of the ratio of saturated over unsaturated fatty acids (sat/unsat) over time (Fig. S3 in the ESM). The ratio evolved similarly in both reactors, starting at 1 and gradually increasing until 2, and thus doubling the level of saturation.

\section{Molecular analyses of the microbial communities}

FISH revealed that only Nitrospira NOB was present in the inoculum and both reactors at day 148 and that Nitrobacter could not be retrieved (data not shown).

For qPCR, AerAOB, AOA, AnAOB and NOB Nitrospira were targeted. AOA were not detected in the inoculum nor in one of the reactors. AerAOB, AnAOB and NOB evolved similarly in both reactors (Fig. S4 in the ESM). AerAOB and Nitrospira copies $\mathrm{ng}^{-1}$ DNA increased with 1 and $2 \log$ units, respectively. The AnAOB copies ng ${ }^{-1}$ DNA however decreased with $1 \log$ unit. When the last qPCR result (Fig. S4 in the ESM, day 158) is compared with the corresponding volumetric activities (Fig. 4(d)), it has to be noted that although no AerAOB activity was detected for almost 1 week, still $3 \times 10^{5}$ and $1 \times 10^{6}$ AerAOB copies $\mathrm{ng}^{-1}$ DNA were measured.

The DGGE profiles for AerAOB confirmed that only some evolution had occurred at the species level, suggesting that salinity did not induce a strong selection towards specialized bacteria (Fig. S5 in the ESM). The effect of temperature on the microbial community was thus similar for both reactors.

\section{Discussion}

This study showed that mesophilic nitrifying sludge can gradually adapt to 42.5 and $47.5^{\circ} \mathrm{C}$ for nitritation and nitratation, respectively. It was shown that a more efficient temperature transition and eventually higher temperatures can be reached through addition of $\mathrm{NaCl}$ at 5 to $7.5 \mathrm{~g} \mathrm{~L}^{-1}$.
Thermophilic nitrogen removal

Numerous thermophilic AOA have already been enriched (de la Torre et al. 2008; Hatzenpichler et al. 2008), which might be derived from the pioneering role under the more extreme conditions of the early Earth (Vlaeminck et al. 2011). In this study, however, no AOA could be detected in the inoculum and in both reactors after 148 days. AerAOB and NOB have also been detected and/or enriched in batch cultures from, for example, hot springs (Golovacheva 1976; Lebedeva et al. 2011). The applications of those thermophilic nitrogenconverting organisms for the treatment of nitrogenous wastewater in reactors are scarce, however. The main nitrogen removal mechanisms in thermophilic activated sludge experiments are ammonia stripping and nitrogen assimilation, accounting for 80 to $100 \%$ of the total nitrogen removal (Abeynayaka and Visvanathan 2011; Kurian et al. 2005). The amount of stripping in this study was minimal, since the nitrogen balance in the elevated temperature periods $\left(>40^{\circ} \mathrm{C}\right)$ could be closed to $>98$ and $>86 \%$ in the control and salt reactor, respectively. The main nitrogen loss occurred during the start-up of the salt reactor (Fig. 4(b, c)). This is the period where AerAOB and NOB were inhibited by the salt addition, so that both ammonium and nitrite became available. Since the reactors were inoculated with AnAOB containing BNR biofilm (Fig. S4 in the ESM), providing anoxic zones, and ammonia stripping and nitrogen assimilation were minimal, the nitrogen loss during the start-up of the salt reactor can thus partly be attributed to AnAOB activity.

Lopez-Vazquez et al. (2013) detected nitrifying activity in mesophilic biomass in short-term batch tests of up to $50{ }^{\circ} \mathrm{C}$, yet the activity after a longer incubation period was not investigated. The results of the present study however showed a complete loss of AerAOB activity upon $48 \mathrm{~h}$ of incubation at $45^{\circ} \mathrm{C}$, demonstrating the need for longer-term reactor experiments to investigate thermophilic nitrification. Similarly, Sudarno et al. (2011) showed that mesophilic nitrifying biomass could not recover at $22.5^{\circ} \mathrm{C}$ after an incubation at $50{ }^{\circ} \mathrm{C}$. In the cited study, ammonia and nitrite oxidation rates in batch assays increased from 12.5 to $40{ }^{\circ} \mathrm{C}$ and were almost zero at $50{ }^{\circ} \mathrm{C}$. Until now, only Shore et al. (2012) focused on the temperature transition of a nitrifying moving bed biofilm reactor, only testing at 40 and $45{ }^{\circ} \mathrm{C}$. At $40{ }^{\circ} \mathrm{C}$, nitrification was still observed at a maximum rate of $144 \mathrm{mg}$ $\mathrm{N} \mathrm{L}^{-1}$ day $^{-1}$, which is comparable to our study. At $45^{\circ} \mathrm{C}$, no nitrification could be achieved. Our study shows that nitrification in engineered systems is also possible above $40{ }^{\circ} \mathrm{C}$. Mesophilic nitrifying sludge could be adapted to $42.5{ }^{\circ} \mathrm{C}$ with nitrification rates of $184 \mathrm{mg}$ $\mathrm{N} \mathrm{L}^{-1}$ day $^{-1}$. Moreover, by using salt addition, NOB could even be further adapted until $47.5{ }^{\circ} \mathrm{C}$ with a nitrite oxidation rate of $302 \mathrm{mg} \mathrm{N} \mathrm{L}^{-1}$ day $^{-1}$. Cooling of warm wastewaters for nitrification could thus partly be avoided 
using transient salt addition, hereby reducing both investment and operating costs.

\section{Effect of salt on nitrification}

In wastewater treatment, salt is considered as a common stress factor inhibiting the autotrophic nitrification (Moussa et al. 2006). Dincer and Kargi (1999) showed that both AerAOB and NOB activities linearly decrease with increasing salt concentrations, with NOB seeming to be more sensitive. Indeed, after the start-up period of the continuous reactors, both AerAOB and NOB activities were lower in the salt reactor compared with those in the control reactor (Fig. 4(d)). Moreover, the decrease in NOB activity in the salt reactor is more pronounced, reflecting the higher sensitivity of NOB towards a salt shock. Nitrifiers can nevertheless adapt to salt concentrations of up to $30 \mathrm{~g} \mathrm{NaCl} \mathrm{L}^{-1}$ (Windey et al. 2005), explaining the absence of NOB inhibition after some weeks (Fig. 4(d)). In the batch activity tests with BNR sludge, NOB showed inhibition with the addition of $5 \mathrm{~g} \mathrm{NaCl} \mathrm{L}^{-1}$ at $45{ }^{\circ} \mathrm{C}$, while AerAOB were stimulated at 40 and $45{ }^{\circ} \mathrm{C}$ (Fig. 3). Interestingly, the NOB inhibition was only observed at $45^{\circ} \mathrm{C}$ and not at 34 and $40{ }^{\circ} \mathrm{C}$, suggesting that, next to the applied $\mathrm{NaCl}$ concentration, temperature has an important role in the salt shock response of NOB. Indeed, the CAS used at operating temperatures of about $15{ }^{\circ} \mathrm{C}$ already showed $91 \%$ NOB inhibition to a salt addition of $5 \mathrm{~g} \mathrm{NaCl} \mathrm{L}-1$ at $34{ }^{\circ} \mathrm{C}$ (Fig. 1). The higher sensitivity of the CAS towards salt stress can potentially also be explained by the lower conductivity of the CAS influent compared with the BNR sludge treating high-strength nitrogenous wastewater.

\section{Stress response versus adaptation and/or selection}

The batch activity tests demonstrated the short-term salt and temperature stress responses. Addition of salt showed an increased direct AerAOB activity at elevated temperatures (Fig. 3), suggesting an interconnection between osmotic and thermal stress response. Bacteria immediately react to stress conditions by expressing those genes whose products are required to deal with the damaging nature of the stress. Firstly, exposure to high osmolarity involves the accumulation of compatible solutes in order to counteract the osmotic stress (Welsh 2000). The role of these small organic compounds is however not limited to osmoprotection and can protect temperature-sensitive enzymes from denaturation and stimulate their renaturation (Caldas et al. 1999). Secondly, osmotic stress can also induce the synthesis of heat-shock proteins (HSP) and hereby initiating the heat-shock response (Feder and Hofmann 1999).

While AerAOB activity in the BNR sludge increased with salt addition at elevated temperatures, the activity of $\mathrm{NOB}$ in the same test decreased at $45^{\circ} \mathrm{C}$ (Fig. 3). As NOB seem more sensitive to salt inhibition (Dincer and Kargi 1999), it is likely that the inhibition effect predominated over the indirect protective effect through the production of HSP or compatible solutes. This was probably also the case for both AerAOB and NOB in the CAS, where salt addition showed no positive effect (Fig. 1). In contrary, a positive NOB effect could be observed in the continuous experiment where NOB were adapted to the added salt concentration. The salt reactor reached NOB activity until $47.5^{\circ} \mathrm{C}$, while the control reactor lost all nitratation activity at that temperature.

In contrast to the direct stress response on the short term, the process of adaptation and/or selection is dominating on a longer term and is clearly reflected in the FAME analysis (Table S1 and Fig. S3 in the ESM). Conventionally, FAME profiles are routinely used as a biomarker for the identification or characterization of microbial communities (Cavigelli et al. 1995), as some FAME profiles can be linked to certain microbial groups or genera. Recently, however, FAME analyses have been used to evaluate the adaptation of certain microorganisms to a particular environmental condition, such as acid environments (Quivey et al. 2000). Indeed, regulation of membrane fluidity through fatty acid alterations is a way for the bacterial membrane to restore the balance between bilayer and non-bilayer-forming lipids when challenged with environmental disturbances such as temperature (Denich et al. 2003). In this study, higher temperatures resulted in a doubling of the ratio of saturated over unsaturated fatty acids, suggesting adaptation (Fig. S3 in the ESM). However, since the DGGE profiles indicate some changes in the microbial community with increasing temperature (Fig. S5 in the ESM), it is inconclusive whether adaptation and/or specialization towards specific species occurred and identification was thus not pursued.

Although a clear temperature effect was observed in the microbial community over time, there were no clear differences between the control and salt reactor, neither in DGGE, qPCR nor FAME data. The communities in both reactors hence responded similarly to higher temperatures, despite the addition of salt. These observations consequently confirm that salt addition interacts mainly on a short term, in the direct stress response, and did not remarkably influence long-term community adaptation/selection at higher temperatures. Further research should clarify this salt-stress response on the gene expression level and identify the development of possible specialized species.

Acknowledgement E.N.P.C was supported as a doctoral candidate (Aspirant), and P.D.S. and S.E.V. were supported as postdoctoral fellows from the Research Foundation Flanders (FWO-Vlaanderen). The reactor equipment used for this study was provided through the Research Grant 1.5.071.13N to S.E.V. from the Research Foundation Flanders (FWOVlaanderen). The authors thank Tim Lacoere for the help with the molecular analyses and Joachim Desloover, Marta Coma, Jo De Vrieze and Joeri Coppens for the inspiring scientific discussions. 


\section{References}

Abeynayaka A, Visvanathan C (2011) Performance comparison of mesophilic and thermophilic aerobic sidestream membrane bioreactors treating high strength wastewater. Bioresour Technol 102(9): $5345-5352$

Barnes D, Bliss PJ (1983) Biological control of nitrogen in wastewater treatment. E. \& F.N. Spon, London

Bell TG, Johnson MT, Jickells TD, Liss PS (2008) Ammonia/ammonium dissociation coefficient in seawater: a significant numerical correction. Environ Chem 5(3):258-U8. doi:10.1071/en07032_co

Caldas T, Demont-Caulet N, Ghazi A, Richarme G (1999) Thermoprotection by glycine betaine and choline. Microbiology (UK) 145:2543-2548

Cavigelli MA, Robertson GP, Klug MJ (1995) Fatty-acid methyl-ester (FAME) profiles as measures of soil microbial community structure. Plant Soil 170(1):99-113

Coutteau P, Sorgeloos P (1995) Intercalibration exercise on the qualitative and quantitative analysis of fatty acids in Artemia and marine samples used in mariculture. ICES Coop Res Rep 211:30, No 211

De Clippeleir H, Courtens E, Mosquera M, Vlaeminck SE, Smets BF, Boon N, Verstraete W (2012) Efficient total nitrogen removal in an ammonia gas biofilter through high-rate OLAND. Environ Sci Technol 46(16):8826-8833

de la Torre JR, Walker CB, Ingalls AE, Konneke M, Stahl DA (2008) Cultivation of a thermophilic ammonia oxidizing archaeon synthesizing crenarchaeol. Environ Microbiol 10(3):810-818

Denich TJ, Beaudette LA, Lee H, Trevors JT (2003) Effect of selected environmental and physico-chemical factors on bacterial cytoplasmic membranes. J Microbiol Methods 52(2):149-182

Dincer AR, Kargi F (1999) Salt inhibition of nitrification and denitrification in saline wastewater. Environ Technol 20(11):1147-1153

Feder ME, Hofmann GE (1999) Heat-shock proteins, molecular chaperones, and the stress response: evolutionary and ecological physiology. Annu Rev Physiol 61:243-282

Fletcher SA, Csonka LN (1998) Characterization of the induction of increased thermotolerance by high osmolarity in Salmonella. Food Microbiol 15(3):307-317

Golovacheva RS (1976) Thermophilic nitrifying bacteria from hot springs. Microbiology 45(2):329-331

Greenberg AE, Clesceri LS, Eaton AD (1992) Standard methods for the examination of water and wastewater. American Public Health Association, Washington DC

Guo JH, Peng YZ, Huang HJ, Wang SY, Ge SJ, Zhang JR, Wang ZW (2010) Short- and long-term effects of temperature on partial nitrification in a sequencing batch reactor treating domestic wastewater. J Hazard Mater 179(1-3):471-479

Hatzenpichler R, Lebedeva EV, Spieck E, Stoecker K, Richter A, Daims H, Wagner M (2008) A moderately thermophilic ammoniaoxidizing crenarchaeote from a hot spring. Proc Natl Acad Sci U S A 105(6):2134-2139

Ilies P, Mavinic DS (2001) The effect of decreased ambient temperature on the biological nitrification and denitrification of a high ammonia landfill leachate. Water Res 35(8):2065-2072

Kurian R, Acharya C, Nakhla G, Bassi A (2005) Conventional and thermophilic aerobic treatability of high strength oily pet food wastewater using membrane-coupled bioreactors. Water Res 39(18):4299-4308

Lapara TM, Alleman JE (1999) Thermophilic aerobic biological wastewater treatment. Water Res 33(4):895-908
Lebedeva EV, Off S, Zumbragel S, Kruse M, Shagzhina A, Lucker S, Maixner F, Lipski A, Daims H, Spieck E (2011) Isolation and characterization of a moderately thermophilic nitrite-oxidizing bacterium from a geothermal spring. FEMS Microbiol Ecol 75(2):195204

Liu SG, Song FY, Zhu NW, Yuan HP, Cheng JH (2010) Chemical and microbial changes during autothermal thermophilic aerobic digestion (ATAD) of sewage sludge. Bioresour Technol 101(24):94389444

Lopez-Vazquez CM, Kubare M, Saroj DP, Chikamba C, Schwarz J, Daims H, Brdjanovic D (2013) Thermophilic biological nitrogen removal in industrial wastewater treatment. Appl Microbiol Biotechnol 98(2):945-956

Lubkowitz-Bailey E, Steidel RC (1999) Investigation of high temperature nitrification. Paper presented at the environmental engineering 1999, New York

Moussa MS, Sumanasekera DU, Ibrahim SH, Lubberding HJ, Hooijmans CM, Gijzen HJ, van Loosdrecht MCM (2006) Long term effects of salt on activity, population structure and floc characteristics in enriched bacterial cultures of nitrifiers. Water Res 40(7):1377-1388

Mulder A (2003) The quest for sustainable nitrogen removal technologies. Water Sci Technol 48(1):67-75

Pynaert K, Smets BF, Wyffels S, Beheydt D, Siciliano SD, Verstraete W (2003) Characterization of an autotrophic nitrogen-removing biofilm from a highly loaded lab-scale rotating biological contactor. Appl Environ Microbiol 69(6):3626-3635. doi:10.1128/aem.69.6. 3626-3635.2003

Quivey RG, Faustoferri R, Monahan K, Marquis R (2000) Shifts in membrane fatty acid profiles associated with acid adaptation of Streptococcus mutans. FEMS Microbiol Lett 189(1):89-92

Shore JL, M'Coy WS, Gunsch CK, Deshusses MA (2012) Application of a moving bed biofilm reactor for tertiary ammonia treatment in high temperature industrial wastewater. Bioresour Technol 112:51-60

Sudarno U, Winter J, Gallert C (2011) Effect of varying salinity, temperature, ammonia and nitrous acid concentrations on nitrification of saline wastewater in fixed-bed reactors. Bioresour Technol 102(10):5665-5673. doi:10.1016/j. biortech.2011.02.078

Suvilampi J, Rintala J (2003) Thermophilic aerobic wastewater treatment, process performance, biomass characteristics, and effluent quality. Rev Environ Sci Biotechnol 2(1):35-51

Vlaeminck SE, Terada A, Smets BF, De Clippeleir H, Schaubroeck T, Bolca S, Demeestere L, Mast J, Boon N, Carballa M, Verstraete W (2010) Aggregate size and architecture determine microbial activity balance for one-stage partial nitritation and anammox. Appl Environ Microbiol 76(3):900-909

Vlaeminck SE, Hay AG, Maignien L, Verstraete W (2011) In quest of the nitrogen oxidizing prokaryotes of the early Earth. Environ Microbiol 13(2):283-295

Vlaeminck SE, De Clippeleir H, Verstraete W (2012) Microbial resource management of one-stage partial nitritation/anammox. Microb Biotechnol 5(3):433-448

Welsh DT (2000) Ecological significance of compatible solute accumulation by micro-organisms: from single cells to global climate. FEMS Microbiol Rev 24(3):263-290

Windey K, De Bo I, Verstraete W (2005) Oxygen-limited autotrophic nitrification-denitrification (OLAND) in a rotating biological contactor treating high-salinity wastewater. Water Res 39(18): $4512-4520$ 